\title{
First report of Leveillula taurica causing powdery mildew on cucumber in Mexico
}

\author{
Hugo Beltrán-Peña ${ }^{1}$ - Alma Rosa Solano-Báez ${ }^{2}$ - Miguel Ángel Apodaca-Sánchez ${ }^{1}$ - Moisés Camacho-Tapia ${ }^{3}$. \\ Rubén Félix-Gastélum ${ }^{1}$ • Juan Manuel Tovar-Pedraza ${ }^{4}$ (I)
}

Received: 10 January 2018 / Accepted: 26 April 2018 / Published online: 8 May 2018

(C) Società Italiana di Patologia Vegetale (S.I.Pa.V.) 2018

During January and February 2017, symptoms and signs of powdery mildew were observed on approx. $30 \%$ of cucumber (Cucumis sativus L.) plants grown in a greenhouse in Ahome, Sinaloa, Mexico. Diseased leaves exhibited chlorotic angular lesions which became necrotic on both leaf surfaces afterwards. Later, white sporulation covered these lesions. A voucher specimen was deposited in the Herbarium of the Department of Agricultural Parasitology at the Chapingo Autonomous University (UACH-H190). Microscopic examination showed conidiophores that were hyaline, erect, straight, cylindrical, measuring $183-268 \times 5.2-6.1 \mu \mathrm{m}$, forming conidia singly. Primary conidia were lanceolate, measuring $54.5-75.2 \times 14.7-18.3 \mu \mathrm{m}$. Secondary conidia were subcylindrical to cylindrical, measuring $50.8-71.2 \times$ 13.1-15.7 $\mu \mathrm{m}$. Chasmothecia were not observed. The morphology of the fungus was consistent with that of

Juan Manuel Tovar-Pedraza

jmtovar@colpos.mx

1 Departamento de Ciencias Biológicas, Universidad Autónoma de Occidente, Unidad Los Mochis, 81223 Los Mochis, Sinaloa, Mexico

2 Colegio de Postgraduados, Campus Montecillo, Fitopatología, 56230 Texcoco, Estado de México, Mexico

3 Laboratorio Nacional de Investigación y Servicio Agroalimentario y Forestal, Universidad Autónoma Chapingo, 56230 Texcoco, Estado de México, Mexico

4 Departamento de Parasitología Agrícola, Universidad Autónoma Chapingo, 56230 Texcoco, Estado de México, Mexico
Leveillula taurica (Lév.) G. Arnaud (Braun and Cook 2012). To confirm the identification, genomic DNA was extracted, and the Internal Transcribed Spacer (ITS) region was amplified using the primers ITS5/ITS4, and sequenced. A BLASTn search of the sequence (GenBank Accession No. MG571545) showed $99 \%$ identity to those of L. taurica on Capsicum annuum L. from Mexico (KU886148) and Catharanthus roseus (L.) G. Don from USA (KF703447). Pathogenicity was confirmed by gently dusting conidia from infected leaves onto 10 healthy leaves of 1-month-old cucumber plants. Ten leaves sprayed with sterile distilled water served as controls. All plants were maintained in a glasshouse at temperatures ranging from 25 to $35{ }^{\circ} \mathrm{C}$. All inoculated plants developed chlorotic angular lesions 8 days after inoculation, whereas the control plants remained symptomless. The fungus present on the inoculated plants was morphologically identical to that of the originally observed on field samples. Leveillula taurica has been reported on cucumbers in Bulgaria, Greece, USA, Israel, Japan, Kenya, Lebanon, Libya, Morocco, Romania, Senegal, and USSR (Farr and Rossman 2018). To our knowledge, this is the first report of powdery mildew caused by $L$. taurica on cucumber in Mexico.

\section{References}

Braun U, Cook RTA (2012) Taxonomic manual of the erysiphales (Powdery Mildews). CBS Biodiversity Series No. 11. CBS, Utrecht, The Netherlands

Farr DF, Rossman AY (2018) Fungal databases, syst. Mycol. Microbiol. Lab., Online publication. ARS, USDA. Retrieved January 10, 2018 